\title{
PERAN PEMERINTAH KOTA SERANG DALAM KEBIJAKAN PENGEMBANGAN PASAR TRADISIONAL
}

\section{The Role Of City Government Serang In Developing Traditional Market Policy}

\author{
Abdul Halik \\ Badan Penelitian dan Pengembangan Kementerian Dalam Negeri \\ Jalan Kramat Raya No. 132 Jakarta Pusat. \\ E-mail: liknph@yahoo.com \\ Dikirim: 28 Februari 2014; direvisi: 15 Maret 2014; disetujui: 12 Mei 2014
}

\begin{abstract}
Abstrak
Dalam pelaksanaan kebijakan pengembangan pasar tradisional banyak melibatkan stakeholders. Masingmasing stakeholders yang terlibat memiliki peran atau keterlibatan yang berbeda-beda. Tujuan kajian ini adalah untuk mendeskripsikan, mengidentifikasi, dan menganalisis peran atau keterlibatan stakeholders dalam kebijakan pengembangan pasar tradisional. Kajian ini menggunakan metode atau pendekatan penelitian deskriptif kualitatif. Hasil kajian ini adalah ada 3 (tiga) bentuk peran atau tingkat keterlibatan stakeholders dalam kebijakan pengembangan pasar tradisional selama ini di Kota Serang, yaitu: (1) AMP Kota Serang terlibat/berperan sebagai penerima informasi, (2) Disperindagkop serta Bappeda Kota Serang terlibat/berperan sebagai pengambil keputusan, dan (3) UPTD Pasar, DTK, BLHD, dan DPKD Kota Serang terlibat/berperan sebagai pemberi pertimbangan. Namun, tidak semua stakeholders (penerima informasi dan pemberi pertimbangan) dilibatkan dalam kebijakan pengembangan pasar tradisional di Kota Serang. Padahal stakeholder ini sangat diperlukan untuk memberikan masukan atau pertimbangan dalam kebijakan pengembangan pasar tradisional sesuai dengan masing-masing Tupoksinya.

Kata kunci: peran, pemerintah, pengembangan, pasar tradisional.
\end{abstract}

\begin{abstract}
In the traditional market development policy implementation involves many stakeholders. Each of the stakeholders involved have a role or involvement of different. The purpose of this study is to describe, identify, and analyze the role or involvement of stakeholders in the policy development of the traditional market. This study uses method or descriptive qualitative research approach. Contribution of this study is to strengthen the role of stakeholders in the policy development of the traditional markets in Banten Province by strengthening the authority, strengthening policy/regulation, strengthening human resources and strengthening budget. The result of this review is that there are three (3) forms of role or level of involvement of stakeholders in policy development during this traditional market in the city of Serang, namely: (1) AMP Serang engagelact as a receiver of information, (2) Disperindagkop and Bappeda Serang involved/role as decision maker, and (3) UPTD Market, DTK, BLHD, and DPKD Serang involved/take the role of consideration. However, not all stakeholders (recipients and providers of information considerations) are involved in policy development in the traditional market city of Serang. Though this is very necessary stakeholders to provide input or consideration in policy development of traditional markets in accordance with their respective duties.

Keywords: roles, government, development, traditional market.
\end{abstract}

\section{PENDAHULUAN}

Salah satu entitas yang secara langsung ikut berkompetisi dalam spirit persaingan perekonomian adalah pasar tradisional. Pasar tradisional di Indonesia merupakan salah satu sektor yang memiliki posisi yang strategis dalam pembangunan perekonomian di Indonesia. Kestrategisan fungsi dan peran pasar tradisional dalam perekonomian daerah, juga ditunjukkan dari kontribusinya dalam Pendapatan Asli Daerah (PAD). Posisi yang sangat strategis dari eksistensi pasar tradisional, juga karena pasar tersebut masih merupakan wadah utama bagi penjualan produk-produk berskala ekonomi rakyat seperti petani, nelayan, pedagang barang kerajinan tangan, dan produk industri rumah tangga (industri rakyat).
Namun, dengan adanya kebijakan penghapusan bisnis perdagangan eceran skala besar dan perdagangan besar dari negative list bagi penanaman modal asing, membuat pertumbuhan pasar moderen meningkat pesat dan mulai memberikan dampak negarif pada eksistensi pasar tradisional. Dalam kenyataannya, para pemain lama dalam skenario perdagangan yang telah berkibar selama puluhan tahun kini harus menghadapi gempuran dari pelaku bisnis yang lebih segar, canggih, dan menarik seperti hypermarket, minimarket, mall, dan supermarket yang dalam kerangka kajian ini disebut sebagai entitas pasar moderen.

Pada sisi lain, eksistensi pasar tradisional yang yang terkesan kumuh, dagangan yang kurang higienis, masih rendahnya kesadaran pedagang untuk mengembangkan usahanya, dan belum optimalnya 
waktu operasi pasar merupakan beberapa faktor tersisihnya pasar tradisional saat ini. Selain itu, pengelolaan pasar tradisional di Indonesia masih semrawut dan kurang memuaskan, dan akibatnya pasar tradisional kehilangan daya saingnya. Namun, dengan di berlakukannya otonomi daerah, membuka peluang kembali bagi daerah untuk mengelola dan mengembangkan pasar tradisional yang tujuannya dapat meningkatkan tingkat kesejahteraan masyarakat.

Kebijakan pengembangan pasar tradisional memang perlu dilakukan, karena hal ini merupakan amanat dari pasal 33 dalam UUD 1945, yang menyebutkan bahwa perekonomian nasional berdasarkan demokrasi ekonomi yang berpihak pada rakyat. Dengan demikian, untuk dapat mengelola dan mengembangkan pasar tradisional, perlu dibuat strategi-strategi atau kebijakan pengembangan pasar tersebut yang sesuai dan dengan memperhatikan faktor internal dan eksternal. Secara nasional, kebijakan pemerintah mengenai pengembangan pasar tradisional dapat dicermati dalam regulasi Peraturan Presiden No. 112 Tahun 2007 Tentang Penataan dan Pembinaan Pasar Tradisional, Pusat Perbelanjaan, dan Toko Modern, serta Permendagri No. 20 Tahun 2012 Tentang Pengelolaan dan Pemberdayaan Pasar Tradisional.

Pertanyaan yang dapat dimunculkan terkait dengan permasalahan di atas adalah, mengapa proses perkembangan dua entitas pelaku bisnis dan ekonomi tersebut tidak sejalan dan cenderung menimbulkan ketidakadilan dalam proses dan dalam pemberdayaannya? Apakah hal ini terjadi sebagai akibat kurangnya sentuhan peran atau keterlibatan stakeholders kebijakan yang dapat membatasi semakin melebarnya jurang diskriminatif serta terkesan sangat subjektif ini? Hal ini menarik dikaji dari sudut pandang kajian implementasi kebijakan publik, khususnya terkait dengan pelaksanaan peran stakeholder dalam suatu kebijakan.

Salah satu aspek penting dalam suatu kebijakan adalah strakeholders atau pemangku kepentingan. Atau, dalam sebuah suatu kebijakan terdapat sebuah pihak yang disebut dengan stakeholder. Pihak stakeholder ini merupakan pihak pemangku kepentingan dalam suatu kebijakan yang dapat mempengaruhi atau dipengaruhi oleh tindakan dari pelaksanaan program secara keseluruhan. Oleh karena itu, perlu diperkuat perannya. Stakeholder dalam organisasi pemerintah adalah berbagai pihak yang memiliki hubungan langsung maupun tidak langsung dengan sukses tidaknya proses program yang berlangsung. Semakin beragam kepentingan dan semakin terdistribusi kekuasaan di tangan masingmasing pemangku kepentingan, maka semakin tinggi kompleksitas dari stakeholder management. Meskipun demikian, secara umum, pola kekuatan para pemangku kepentingan dapat diidentifikasi melalui stakeholder matrix.

Hambatan pelaksanaan dan tingkat keberhasilan kebijakan pengembang- an pasar tradisional dapat dipengaruhi oleh peran atau keterlibatan stakeholders. Idealnya, pemerintah atau pemerintah daerah harus melibatkan seluruh stakeholders yang benar-benar memiliki kepentingan terhadap kebijakan pengembangan pasar tradisional, baik dalam perencanaan maupun dalam proses pelaksanaan kebijakan tersebut. Peran atau keterlibatan stakeholders dapat diketahui dengan menelusuri kepentingan dan pengaruh (sikap dan kekuatan SDM, finansial, dan politik) dari setiap stakeholders yang terlibat. Namun, menurut Istiningtyas (2008), salah satu kegagalan kebijakan pengembangan pasar tradisional adalah karena tidak semua stakeholders yang berkepentingan dalam kebijakan pengembangan pasar tradisional dilibatkan dalam perencanaan dan proses pelaksanaan kebijakan tersebut.

Uraian-uraian di atas merupakan argumen rasionalitas "kemengapaan" pentingnya dikaji analisis peran atau keterlibatan stakeholder dalam kebijakan pengembangan pasar tradisional. Sebab, tanpa peran atau pelibatan seluruh stakeholder, tentunya tujuan dari kebijakan pengembangan pasar tradisional akan sulit sekali dicapai. Peran atau keterlibatan seluruh stakeholder dalam kebijakan pengembangan pasar tradisional sangat diperlukan dalam perencanaan dan proses pelaksanaan kebijakan tersebut. Konkritnya, urgensi dilakukan analisis stakeholder adalah untuk mengidentifikasi minat atau sikap, kepentingan, dan pengaruh para stakeholder terhadap kegiatan program yang sedang berjalan.

Pokok permasalahan dalam kajian ini adalah peran atau pelibatan stakeholders yang dikaitkan dengan tingkat keberhasilan kebijakan pengembangan pasar tradisional, dengan rumusan masalah sebagai berikut: (1) Apa peran atau keterlibatan stakeholders dalam kebijakan pengembangan pasar tradisional?; (2) Apakah stakeholders telah dilibatkan atau melaksanakan perannya dalam pengembangan pasar tradisional?; dan (3) Bagaimana sebaiknya penguatan peran stakeholders agar pasar tradisional dapat berkompetisi dengan toko moderen dan pusat perbelanjaan?

Adapun tujuan kajian ini adalah: (1) Mengidentifikasi dan menggambarkan peran atau keterlibatan stakeholders dalam kebijakan pengembangan pasar tradisional; (2) Mengetahui terlibat tidaknya atau pelaksanaan peran stakeholders dalam pengembangan pasar tradisional; dan (3) Merumuskan penguatan peran stakeholders yang dapat membuat pasar tradisional berkompetisi dengan toko moderen dan pusat perbelanjaan.

Untuk menjawab permasalahan di atas diperlukan acuan teoretik atau konseptual. Konsep stakeholder pertama kali digunakan dalam sebuah memorandum internal 1963 di Stanford Research. Lembaga ini mendefinisikan pemangku kepentingan sebagai kelompok-kelompok yang tanpa dukungan organisasi akan berhenti untuk eksis. Teori ini kemudian dikembangkan dan diperjuangkan oleh Freeman (1984) yang mengidentifikasi stakeholder 
sebagai kelompok atau individu yang dapat mempengaruhi atau dipengaruhi oleh suatu pencapaian tertentu.

Stakeholder dapat diartikan sebagai segenap pihak yang terkait dengan isu dan permasalahan yang sedang diangkat. Misalnya, bilamana isu perikanan, maka stakeholder dalam hal ini adalah pihak-pihak yang terkait dengan isu perikanan, seperti nelayan, masyarakat pesisir, pemilik kapal, anak buah kapal, pedagang ikan, pengolah ikan, pembudidaya ikan, pemerintah, pihak swasta di bidang perikanan, dan sebagainya. Stakeholder dalam hal ini dapat juga dinamakan pemangku kepentingan (http:www.id. wikipedia.org/wiki/pemangku_kepentingan.).

Pengertian stakeholder dan istilah stakeholder sudah sangat populer. Kata ini telah dipakai oleh banyak pihak dan hubungannnya dengan berbagi ilmu atau konteks, misalnya manajemen bisnis, ilmu komunikasi, pengelolaan sumberdaya alam, sosiologi, dan lain-lain. Lembaga-lembaga publik telah menggunakan istilah stakeholder ini secara luas ke dalam proses-proses pengambilan dan implementasi keputusan. Secara sederhana, stakeholder sering dinyatakan sebagai para pihak, lintas pelaku, atau pihak-pihak yang terkait dengan suatu isu atau suatu rencana.

Beberapa defenisi yang penting dikemukakan seperti Freeman (1984) yang mendefenisikan stakeholder sebagai kelompok atau individu yang dapat memengaruhi dan atau dipengaruhi oleh suatu pencapaian tujuan tertentu. Adapun Biset (2008) secara singkat mendefenisikan stekeholder sebagai orang dengan suatu kepentingan atau perhatian pada permasalahan. Stakeholder ini sering diidentifikasi juga dengan suatu dasar tertentu, yaitu dari segi kekuatan dan kepentingan relatif stakeholder terhadap issu, dan dari segi posisi penting dan pengaruh yang dimiliki mereka.

Chariri dan Ghazali (2007) mengatakan bahwa organisasi bukanlah entitas yang hanya beroperasi untuk kepentingannya sendiri, namun harus memberikan manfaat bagi stakeholders-nya (shareholders, kreditor, konsumen, supplier, pemerintah, masyarakat, analis, dan pihak lain). Adapun menurut Rudito (2004), organisasi dianggap sebagai stakeholders, jika mem- punyai 3 (tiga) atribut, yaitu: kekuasaan, legitimasi, dan kepentingan.

Dengan demikian, dalam suatu aktivitas organisasi dipengaruhi oleh faktor-faktor dari luar dan dari dalam, yang kesemuanya dapat disebut sebagai stakeholders. Kelangsungan hidup organisasi bergantung pada dukungan stakeholders dan dukungan tersebut harus dicari sehingga aktivitas organisasi adalah untuk mencari dukungan tersebut. Makin powerful stakeholders, makin besar usaha organisasi untuk beradaptasi. Pengungkapan sosial dianggap sebagai bagian dari dialog antara organisasi dengan stakehoders-nya (Chariri dan Ghazali, 2007).

Jadi, istilah 'Stakeholders' atau dinamakan pemangku kepentingan adalah kelompok atau individu yang dukungannya diperlukan demi kesejahteraan dan kelangsungan hidup organisasi. Pemangku kepentingan adalah seseorang, organisasi atau kelompok dengan kepentingan terhadap suatu sumberdaya alam tertentu (Rudito, 2007). Stakeholder is a person who has something to gain or lose through the outcomes of a planning process, programme or project (Schmeer, 2007). Pemangku kepentingan mencakup semua pihak yang terkait dalam pengelolaan terhadap sumberdaya. Menurut Witold Henisz guru besar pada Sekolah Bisnis Wharton, termasuk semua orang dari politisi lokal dan nasional dan tokoh atau pemimpin masyarakat, penguasa, kelompok paramiliter, LSM dan badan-badan internasional. Dalam konteks perusahaan, Donaldson dan Preston (1995) memberikan definisi pemangku kepentingan secara lebih khusus sebagai suatu kelompok atau individu yang menanggung suatu jenis risiko baik karena mereka telah melakukan investasi (material ataupun manusia) di perusahaan tersebut ('Stakeholders sukarela'), ataupun karena mereka menghadapi risiko akibat kegiatan perusahaan tersebut ('Stakeholders non-sukarela'). Berdasarkan pandangan tersebut pemangku kepentingan adalah pihak yang akan dipengaruhi secara langsung oleh keputusan dan strategi perusahaan.

Dalam Bussiness Dictionary, pemangku kepentingan didefinisikan kelompok atau organisasi yang memiliki kepentingan langsung atau tidak langsung dalam sebuah organisasi karena dapat mempengaruhi atau dipengaruhi oleh tindakan organisasi, tujuan, dan kebijakan. Meskipun para pelaku biasanya melegitimasi dirinya sebagai stakeholder, tetapi semua pemangku kepentingan tidak sama dan memiliki kedudukan yang berbeda. Misalnya, pelanggan perusahaan berhak untuk praktek perdagangan yang adil tetapi mereka tidak berhak untuk mendapat pertimbangan yang sama sebagai karyawan perusahaan. Pemangku kepentingan kunci lain dalam organisasi bisnis diantaranya kreditor, pelanggan, direksi, karyawan, pemerintah (dan badanbadannya), pemilik (pemegang saham), pemasok, serikat pekerja, dan masyarakat dari mana bisnis menarik sumberdaya yang dimiliki.

Berdasarkan definisi di atas dapat disimpulkan bahwa pemangku kepentingan adalah seluruh pihak yang terkait dengan isu dan permasalahan yang menjadi fokus kajian atau perhatian. Misalnya terkait isu perikanan, maka makna pemangku kepentingan sebagai para pihak yang terkait dengan isu perikanan, seperti nelayan, masyarakat pesisir, pemilik kapal, anak buah kapal, pedagang ikan, pengolah ikan, pembudidaya ikan, pemerintah, pihak swasta di bidang perikanan, dan sebagainya. Seorang pemangku kepentingan adalah seseorang yang mempunyai sesuatu yang dapat ia peroleh atau akan kehilangan akibat dari sebuah proses perencanaan atau proyek. Dalam banyak siklus, mereka disebut sebagai kelompok kepentingan, dan mereka bisa mempunyai posisi yang kuat dalam menentukan hasil suatu proses 
politik. Seringkali akan sangat bermanfaat bagi proyek penelitian untuk mengidentifikasi dan menganalisis kebutuhan dan kepedulian berbagai pemangku kepentingan, terutama jika proyek diracang bertujuan mempengaruhi kebijakan (http://www.smeru.or.id/).

Konkritnya, pandangan-pandangan di atas menunjukkan bahwa pengenalan stakeholder tidak sekedar menjawab pertanyaan siapa stekholder suatu isu, tetapi juga sifat hubungan stakeholder dengan isu, sikap, pandangan, dan pengaruh stakeholder itu. Aspek-aspek ini sangat penting dianalisis untuk mengenal stakeholder.

Beberapa istilah penting dalam kerangka definisi pemangku kepentingan, di antaranya: (1) Stakeholder Engagement is the process of effectively eliciting stakeholders' views on their relationship with the organisation/ programmel project; (2) Stakeholder Analysis is a technique used to identify and assess the influence and importance of key people, groups of people, or organisations that may significantly impact the success of your activity or project; dan (3) Stakeholder Management is essentially stakeholder relationship management as it is the relationship and not the actual stakeholder groups that are managed (Schmeer, 2007).

Berdasarkan kekuatan, posisi penting, dan pengaruh stakeholder terhadap suatu isu stakeholder dapat diketegorikan ke dalam beberapa kelompok. Branco, Castelo, dan Rodriguez (2007) mengelompkkan stakeholder ke dalam 3 (tiga) kategori, yaitu: (1) stakeholder utama (primer), (2) stakeholder sekunder pendukung (sekunder), dan (3) stakeholder kunci.

Sebagai gambaran pengelompokan tersebut pada berbagai kebijakan, program, dan proyek pemerintah (publik) dapat kemukakan kelompok stakeholder seperti berikut:

\section{Stakeholder Utama (Primer)}

Stakeholder yang memiliki kaitan kepentingan secara langsung dengan suatu kebijakan, program, dan proyek. Mereka harus ditempatkan sebagai penentu utama dalam proses pengambilan keputusan. Stakeholder utama ini antara lain: (a) Masyarakat dan tokoh masyarakat, seperti masyarakat yang terkait dengan proyek, yakni masyarakat yang diidentifkasi akan memperoleh manfaat dan yang akan terkena dampak (misalnya, kehilangan tanah dan kemungkinan kehilangan mata pencaharian) dari suatu proyek. Demikian halnya dengan tokoh masyarakat, yaitu anggota masyarakat yang oleh masyarakat ditokohkan di wilayah itu sekaligus dianggap dapat mewakili aspirasi masyarakat; dan (b) Pihak manajer publik, yaitu lembaga/badan publik yang bertanggung jawab dalam pengambilan dan implementasi suatu keputusan.

Pengambil kebijakan adalah baik yang ada di lembaga pemerintahan maupun lembaga non pemerintah, mereka yang menjabat sebagai pimpinan (leader), mempunyai kewenangan membuat kebijakan dalam lembaganya. Kebijakan yang didasarkan pada undang-undang atau aturan negara/lembaga/institusi, mempunyai permasalahan pembangunan yang sering muncul dan mempunyai tujuan meniadakan permasalahan yang sering muncul.

Pemberi pelayanan adalah mereka yang melaksanakan program pembangunan atau mereka yang memberikan pelayanan (provider). Mereka ini, akan bekerja sesuai dengan pengetahuan dan keterampilan yang dimiliki. Misalnya saja dibidang kesehatan, mereka yang tergolong provider adalah dokter, perawat, bidan, tenaga gizi, sanitarian, dan petugas kesehatan masyarakat lainnya. Pemberi pelayanan yang bersifat publik (masyarakat) atau kelompok masyarakat bukan yang bersifat induvidu, walaupun dalam masyarakat itu sendiri terdapat induvidu-induvidu. Induvidu yang bersifat publik adalah individu yang mempunyai permasalahan yang sama. Misalnya orang yang tidak mempunyai $W C$ atau orang yang membuang hajat disembarang tempat. Atau, juga orang-orang yang sakit dengan penyakit yang sama, bila dipresentasekan telah dikategorikan sebagai masalah kesehatan masyarakat bukan masalah induvidu.

Penerima dampak adalah orang-orang yang berkepentingan, yang selalu disebut tetapi selalu diabaikan, yang selalu menjadi sasaran pembangunan tetapi bukan dijadikan subjek melainkan objek, yang selalu didiskusikan, dibicarakan tetapi tidak dilibatkan dalam diskusi dan pembicaraan. Mereka (orang-orang yang berkepentingan) itu adalah penerima pelayanan, penerima dampak dari suatu pembangunan, yaitu masyarakat atau kelompok masyarakat, atau induviduinduvidu yang mempunyai masalah yang sama.

\section{Stakeholder Pendukung (Sekunder)}

Stakeholder yang tidak memiliki kaitan kepentingan secara langsung terhadap suatu kebijakan, program, dan proyek, tetapi memiliki kepedulian (consern) dan keprihatinan sehingga mereka turut bersuara dan berpengaruh terhadap sikap masyarakat dan keputusan legal pemerintah. Stakeholder pendukung ini antara lain: (a) Lembaga(aparat) pemerintah dalam suatu wilayah tetapi tidak memiliki tanggung jawab langsung; (b) Lembaga pemerintah yang terkait dengan isu tetapi tidak memiliki kewenangan secara langsung dalam pengambilan keputusan: (c) Lembaga Swadaya Masyarakat (LSM) setempat, yaitu LSM yang bergerak di bidang yang bersesuai dengan rencana, manfaat, dan dampak yang muncul yang memiliki "concern", termasuk organisasi massa yang terkait; (d) Perguruan Tinggi, yaitu kelompok akademisi ini memiliki pengaruh penting dalam pengambilan keputusan pemerintah; dan (e) Pengusaha (badan usaha) yang terkait.

\section{Stakeholder Kunci}

Stakeholder yang memiliki kewenangan secara legal dalam hal pengambilan keputusan. Stakeholder kunci yang dimaksud adalah unsur eksekutif sesuai levelnya, legislatif, dan instansi. Misalnya, stekeholder 
kunci untuk suatu keputusan untuk suatu proyek level daerah kabupaten (pemerintah kabupaten, DPRD kabupaten, dan dinas yang membawahi langsung proyek yang bersangkutan).
Istiningtyas
(2008)
mengelompokkan

stakeholders berdasarkan besar kecilnya pengaruh atau kepentingan terhadap suatu kebijakan, yaitu:

1. Stakeholders Utama.

Mereka yang mempunyai pengaruh yang lemah terhadap lahirnya suatu kebijakan/ keputusan tetapi kesejahteraan mereka sangat penting dipertimbangkan bagi pengambil kebijakan/keputusan. Dalam hal ini adalah masyarakat yang berada di sekitar areal yang akan dikembangkan serta pihak lain yang memanfaatkan wilayah tersebut.

\section{Stakeholders Sekunder (Tingkat Kedua)}

Mereka yang mempengaruhi keputusan/ kebijakan pada saat kebijakan dibuat (pembuat kebijakan) dan pihak yang terkait dengan implementasi kebijakan tersebut. Pada program pengembangan pasar tradisional misalnya, yang menjadi stakeholders sekunder adalah pihak pemerintah daerah atau pihak swasta. Jadi, pemangku kepentingan sekunde adalah 'perantara', yaitu, orang atau organisasi yang secara tidak langsung dipengaruhi oleh tindakan organisasi.

\section{Stakeholders Eksternal}

Individu atau group yang dapat menggunakan pengaruhnya, misalnya, dengan melakukan lobi kepada pembuat keputusan. Stakeholders eksternal adalah Lembaga Swadaya Masyarakat (LSM) dan pemerhati lingkungan (Brown et al. dalam Firman, 2013).

Selanjutnya, Kasali dalam Wibisono (2007) membagi stakeholders menjadi:

1. Stakeholders Internal dan Eksternal.

Stakeholders internal adalah stakeholders yang berada di dalam lingkungan organisasi. Misalnya karyawan, manajer, dan pemegang saham (shareholder). Stakeholders eksternal adalah stakeholders yang berada di luar lingkungan organisasi, seperti penyalur atau pemasok, konsumen atau pelanggan, masyarakat, pemerintah, pers, kelompok social responsible investor, licensing partner, dan lain-lain.

2. Stakeholders Primer, Sekunder, dan Marjinal.

Pemangku kepentingan primer atau 'key stakeholder' adalah mereka yang pada akhirnya terpengaruh, baik secara positif atau negatif oleh tindakan organisasi.

Pemangku kepentingan primer adalah 'pihak di mana tanpa partisipasinya yang berkelanjutan organisasi tidak dapat bertahan.' Contohnya adalah pemegang saham, investor, pekerja, pelanggan, dan pemasok. Menurut Wibisono (2007), suatu perusahaan atau organisasi dapat didefinisikan sebagai suatu sistem pemangku kepentingan primer yang merupakan rangkaian kompleks hubungan antara kelompok-kelompok kepentingan yang mempunyai hak, tujuan, harapan, dan tanggung jawab yang berbeda.

Pemangku kepentingan sekunder didefinisikan sebagai "pihak yang mempengaruhi atau dipengaruhi oleh perusahaan, tapi mereka tidak terlibat dalam transaksi dengan perusahaan dan tidak begitu penting untuk kelangsungan hidup perusahaan.' Contohnya adalah media dan berbagai kelompok kepentingan tertentu. Perusahaan tidak bergantung pada kelompok ini untuk kelangsungan hidupnya, tapi mereka bisa mempengaruhi kinerja perusahaan dengan mengganggu kelancaran bisnis perusahaan.

Tidak semua elemen dalam stakeholders perlu diperhatikan. Organisasi perlu menyusun skala prioritas. Stakeholders yang paling penting disebut stakeholders primer, stakeholders yang kurang penting disebut stakeholders sekunder, dan yang biasa diabaikan disebut stakeholders marjinal. Urutan prioritas ini berbeda bagi setiap organisasi, meskipun produk atau jasanya sama. Urutan ini juga bisa berubah dari waktu ke waktu.

3. Stakeholders Tradisional dan Masa Depan.

Karyawan dan konsumen dapat disebut sebagai stakeholders tradisional, karena saat ini sudah berhubungan dengan organisasi. Adapun stakeholders masa depan adalah stakeholders pada masa yang akan datang diperkirakan akan memberikan pengaruhnya pada organisasi seperti mahasiswa, peneliti, dan konsumen potensial.

4. Proponents, Opponents, dan Uncommitted.

Diantara stakeholders ada kelompok yang memihak organisasi (proponents), menentang organisasi (opponents), dan ada yang tidak peduli atau abai (uncommitted). Organisasi perlu mengenal stakeholders yang berbeda-beda ini agar dapat melihat permasalahan, menyusun rencana dan strategi untuk melakukan tindakan yang proposional.

\section{Silent Majority dan Vokal Minority.}

Dilihat dari aktivitas stakeholders dalam melakukan komplain atau mendukung organisasi, tentu ada yang menyatakan pertentangan atau dukungannya secara vokal (aktif), namun ada pula yang menyatakan secara silent (pasif). Menurut Hill (2006), stakeholders dalam pelayanan sosial meliputi negara, sektor pivat, Lembaga Swadaya Masyarakat (LSM), dan masyarakat. Mereka memiliki kepentingan berbeda-beda yang satu dengan yang lain bisa saling berseberangan dan sangat mungkin merugikan pihak yang lain.

Selain pengelompokkan berdasarkan hubungan antara strakeholder dengan issu, stakeholders publik atau apa yang diistilahkan dengan publik relevan dapat dikelompokkan berdasarkan karakteristik pengorganisasiannya, yaitu:

1. Stakeholder publik yang tidak terorganisir. Stakeholder individu yang tidak dapat diwakili 
oleh pihak lain. Masyarakat, tokoh masyarakat, pengamat, dan sebagainya.

2. Stakeholder publik yang terorganisir, stakeholder yang terhimpun dalam suatu organisasi atau kelompok tertentu, dimana pimpinan atau anggota yang ditunjuk dapat mewakili organisasinya memberi pandangan dan sikap dalam proses pengambilan atau implementasi suatu keputusan.

3. Stakeholder yang terorganisir secara semu. Stakeholder yang memiliki organisasi atau kelompok tertentu, tetapi tidak memiliki perwakilan dalam pengambilan keputusan. Pemimpin dan anggota diberi kebebasan bersikap dan berpandangan sehingga biasanya anggotanya tidak bisa bertindak atas nama organisasi. Misalnya, beberapa organisasi informal di masyarakat, LSM-LSM, dan sebagainya (Mursitama, 2011).

Dalam proses pengambilan keputusan, suatu isu dapat berhubungan dengan salah satu karakteristik stakeholder atau kombinasi stakeholder tersebut. Maksudnya, suatu keputusan yang akan diambil dapat berhubungan stakeholder publik yang tidak terorganisir atau dapat pula berhubungan dengan beberapa stakeholder terorganisir (multi-stakeholder terorganisir). Paling sederhana, berhadapan dengan hanya satu group stakeholder terorganisir, tetapi adakah? Karena itu, makin luas cakupan wilayah isu dan makin tinggi derajat pengaruh issu terhadap berbagai pihak baik dari segi manfaat maupun resiko makin kompleks stakeholdernya. Namun demikian tidak berarti luasnya cakupan dan kompleksnya derajat pengaruh isu tersebut menggiring kita justru menyedarhanakan identifikasi stakeholder dengan sertamerta melibatkan semua unsur yang ada dalam issu bersangkutan tanpa memilah-milah keterkaitannya.

Pengelompokan stakeholder dapat dilihat dari kecendrungan posisi dan pandangan, misalnya kelompok yang terdiri LSM, organisasi masyarakat, tokoh masyarakat, dan masyarakat bawah, dan kelompok yang cenderung netral atau selama ini lebih berafiliasi dengan pemerintah, seperti Perguruan Tinggi, organisasi profesi dan konsultan. Secara umum, karakteristik stakeholder yang meliputi kepentingan/kepedulian, kekuatan pengaruh terhadap keputusan, pengaruh terhadap anggota, cara kerja, social original, dan relasi antar stakeholder. Karakteristik ini sudah meliputi tiga komponen, yaitu kecenderungan sikap, prilaku, dan konteks mereka (http://www.suarapublik.org/

Artikel/stakeholder.htm).

Dalam konteks Stakeholder versus Publik, pengertian stakeholder dalam pengambilan keputusan publik lebih luas daripada istilah publik itu sendiri. Banyak istilah stakeholder sering digunakan dalam arti yang sama. Misalnya, keputusan ini tidak boleh hanya didominasi oleh pemerintah, tetapi harus melibatkan seluruh stakeholder. Jika yang dimaksud adalah stakeholder non-pemerintah, maka seharusnya dinyatakan sebagai stakeholder publik.

Pada kasus lain, pengertian publik lebih luas dari stakeholder. Publik dapat berarti semua warga negara non pemerintah, sementara stakeholder hanya terkait dengan suatu isu/rencana tertentu. Istilah dalam literatur pelibatan publik bahwa yang diidentifikasi sebagai kelompok yang perlu dilibatkan dinyatakan sebagai publik relevan (relevant public). Istilah publik relevan inilah dapat disamakan dengan stakeholder publik. Rietbergen (2008) menyatakan bahwa publik relevan terhadap suatu isu adalah semua representasi group atau individu masyarakat baik yang terorganisir maupun tidak teroganisir masyarakat sebagai publik yang dapat memberikan informasi yang dapat digunakan untuk penyelesaian, dengan kata lain sumber informasi yang tepat dalam pengumpulan data untuk pengambilan keputusan, atau publik yang dapat mempengaruhi kemampuan mengimplementasikan keputusan. Jadi, intinya adalah keterkaitan publik dengan isu, kebijakan, program, dan proyek yang dapat dilihat dari lokasi (manfaat dan resiko) dan ruang kepedulian.

Istilah publik relevan dan istilah stakeholder publik penting diketengahkan karena berbagai tulisan dan pernyataan yang bersifat umum mengenai stakeholder sering mempersamakan kata stakeholder dengan publik tanpa melihat keterkaitannya dengan suatu isu. Suatu perencanaan misalnya sering mempersyaratkan adanya keterlibatan stakeholder. Untuk memenuhi syarat ini, pemrakarsa biasanya langsung mendaftar semua institusi sebagai suatu cara pelibatan stakeholder secara luas. Karena itu tersusunlah daftar panjang instansi-instnasi, LSMLSM, organisasi masyarakat, para pengusaha, perguruan tinggi tanpa melihat keterkaitan antara institusi dengan issu. Padahal keterkaitan tersebutlah yang sangat penting diperhatikan (http://www. suarapublik.org/artikel/stakeholder.htm).

Dalam konteks representasi stakeholder publik. mungkin karena kerumitan pelibatan publik sehingga banyak pihak selalu mempersoalkan sukarnya mengidentifikasi publik yang representatif. Banyak kasus proses pengambilan keputusan yang telah melibatkan unsur non pemerintah tetapi protes atau penolakan dari beberapa pihak masih terjadi. Beberapa pihak menganggap bahwa proses pelibatan publik yang dilakukan hanya formalitas sementara perencana kebijakan merasa telah melibatkan publik secara luas. Ada pula keluhan bahwa pelibatan publik yang lebih luas lagi akan memakan biaya yang sangat besar dan waktu yang sangat lama. Karena itu masalah representasi publik menjadi hal yang sangat penting.

Pertanyaannya adalah: siapa mewakili siapa? dan Apakah wakil-wakil memiliki legitimasi yang kuat dari suatu group? Pertanyaan-pertanyaan ini agaknya sukar dijawab tanpa suatu pengalaman empirik yang memadai. Perlu dicatat, bahwa istilah representasi bukan dalam arti mewakili populasi tetapi mewakili 
sikap dan pandangan publik. Karena itu pula representasi ini tidak boleh dibatasi oleh wilayah administrasi, publik yang proaktif. Mungkin, kriteria representasi yang paling tepat ditetapkan sendiri melalui perundingan diantara mereka. Mereka yang diajak atau dilibatkan dalam perundingan awal adalah mereka mereka yang diidentifikasi sebagai publik yang pro-aktif.

Selanutnya, pasar tradisional merupakan tempat bertemunya penjual dan pembeli serta ditandai dengan adanya transaksi penjual pembeli secara langsung dan biasanya ada proses tawar-menawar, bangunan biasanya terdiri dari kios-kios atau gerai, los dan dasaran terbuka yang dibuka oleh penjual maupun suatu pengelola pasar. Kebanyakan menjual kebutuhan sehari-hari seperti bahan-bahan makanan berupa ikan, buah, sayur-sayuran, telur, daging, kain, pakaian barang elektronik, jasa dan lain-lain. Selain itu, ada pula yang menjual kue-kue dan barang-barang lainnya. Pasar seperti ini masih banyak ditemukan di Indonesia, dan umumnya terletak dekat kawasan perumahan agar memudahkan pembeli untuk mencapai pasar. Beberapa pasar tradisional yang "legendaris" antara lain adalah pasar Beringharjo di Yogyakarta, pasar Klewer di Solo, dan pasar Johar di Semarang. Pasar tradisional di seluruh Indonesia terus mencoba bertahan menghadapi serangan dari pasar moderen.

Pasar Tradisional adalah pasar yang dibangun dan dikelola oleh pemerintah, swasta, koperasi, atau swadaya masyarakat dengan tempat usaha berupa toko, kios atau los dan tenda, yang dimiliki atau dikelola oleh pedagang kecil dan menengah dan koperasi, dengan usaha skala kecil dan modal kecil dengan proses jual beli melalui tawar menawar (Riyadi, 2008).

Jadi, pasar tradisional adalah pasar yang dalam pelaksanaannya bersifat tradisional dan ditandai dengan pembeli serta penjual yang bertemu secara langsung. Proses jual-beli biasanya melalui proses tawar menawar harga, dan harga yang diberikan untuk suatu barang bukan merupakan harga tetap, dalam arti lain masih dapat ditawar, hal ini sangat berbeda dengan pasar moderen. Umumnya, pasar tradisional menyediakan bahan-bahan pokok serta keeprluan rumah tangga. Lokasi pasar tradisional dapat berada ditempat yang terbuka atau bahkan dipingir jalan.

Kebijakan pengelolaan pasar tradisional adalah untuk mendorong pasar tradisional mampu berkompetisi dan berdaya saing dengan pusat perbelanjaan dan toko moderen diperlukan pengelolaan dan pemberdayaan pasar tradisional secara profesional. Pengelolaan pasar tradisional adalah penataan pasar tradisional yang meliputi perencanaan, pelaksanaan dan pengendalian pasar tradisional.

Tujuan pengelolaan dan pemberdayaan pasar tradisional meliputi: menciptakan pasar tradisional yang tertib, teratur, aman, bersih, dan sehat, meningkatkan pelayanan kepada masyarakat, menjadikan pasar tradisional sebagai penggerak roda perekonomian daerah, dan menciptakan pasar tradisional yang berdaya saing dengan pusat perbelanjaan dan toko moderen. Ruang lingkupnya meliputi pengelolaan dan pemberdayaan pasar tradisional yang dimiliki, dibangun dan/atau dikelola oleh Pemerintah Daerah.

Dari segi perencanaan, Bupati/walikota melalui kepala SKPD melakukan perencanaan pasar tradisional. Perencanaan pasar tradisional yang dimaksud meliputi perencanaan fisik dan perencanaan non fisik. Perencanaan fisik meliputi: penentuan lokasi; penyediaan fasilitas bangunan dan tata letak pasar; dan sarana pendukung. Perencanaan fisik berlaku untuk pembangunan pasar baru. Perencanaan fisik lainnya berlaku untuk rehabilitasi pasar lama.

Penentuan lokasi antara lain: mengacu pada RTRW Kabupaten/Kota; dekat dengan pemukiman penduduk atau pusat kegiatan ekonomi masyarakat; dan memiliki sarana dan prasarana transportasi yang menghubungkan ibukota kabupaten/kota dan ibukota kecamatan dengan lokasi pasar baru yang akan dibangun.

Fasilitas bangunan dan tata letak pasar antara lain: bangunan toko/ kios/los dibuat dengan ukuran standar ruang tertentu; petak atau blok dengan akses jalan pengunjung ke segala arah; pencahayaan dan sirkulasi udara yang cukup; penataan toko/kios/los berdasarkan jenis barang dagangan; dan bentuk bangunan pasar tradisional selaras dengan karakteristik budaya daerah.

Sarana pendukung antara lain: kantor pengelola; areal parkir; tempat pembuangan sampah sementara/sarana pengelolaan sampah; air bersih; sanitasi/drainase; tempat ibadah; toilet umum; pos keamanan; tempat pengelolaan limbah/Instalasi Pengelolaan Air Limbah; hidran dan fasilitas pemadam kebakaran; penteraan; sarana komunikasi; dan area bongkar muat dagangan.

Perencanaan non fisik untuk melaksanakan kegiatan-kegiatan sesuai dengan standar operasional dan prosedur yang ditetapkan. Standar operasional dan prosedur, antara lain: Sistem penarikan retribusi; Sistem keamanan dan ketertiban; Sistem kebersihan dan penanganan sampah; Sistem perparkiran; Sistem pemeliharaan sarana pasar; Sistem penteraan; dan Sistem penanggulangan kebakaran. Rencana fisik dan non fisik disusun dalam RPJMD dan Renstra SKPD sesuai dengan peraturan perundang-perundangan. Rencana fisik dan non fisik dijabarkan ke dalam Renja SKPD dan RKPD sebagai landasan penyusunan Rancangan APBD.

Dari aspek kelembagaan, Bupati/walikota menetapkan struktur organisasi pengelola pasar tradisional dengan Keputusan Bupati/Walikota. Struktur organisasi pengelola pasar tradisional paling sedikit terdiri dari: kepala pasar; pejabat keuangan; dan pejabat teknis lainnya sesuai kebutuhan. Bupati/walikota menetapkan kepala pasar, pejabat 
keuangan dan pejabat teknis lainnya dengan Keputusan Bupati/Walikota berdasarkan usulan kepala SKPD.

Persyaratan pemakaian tempat usaha, antara lain: pedagang yang memanfaatkan tempat usaha harus memiliki SITU; dan pedagang yang memiliki SITU dilarang mengalihkan kepada pihak lain. Kewajiban pemakai tempat usaha, antara lain: menjaga keamanan, kebersihan dan ketertiban tempat usaha; menempatkan dan menyusun barang dagangan secara teratur; menyediakan tempat sampah pada ruang usahanya; membayar retribusi pelayanan pasar tepat waktu; dan mematuhi peraturan yang dikeluarkan pengelola.

Dari aspek pelaksanaan, Bupati/walikota melalui kepala SKPD melaksanakan kegiatan sesuai dengan rencana fisik dan non fisik yang dianggarkan dalam APBD. Bupati/walikota dapat melakukan kerjasama dengan pihak ketiga untuk pembangunan pasar baru, rehabilitasi pasar lama, dan pengelolaan pasar tradisional. Kerjasama dengan pihak ketiga dapat dilaksanakan dengan pola Bangun Guna Serah, Bangun Serah Guna, dan Kerja Sama Pemanfaatan lainnya. Kerjasama dilaksanakan sesuai dengan peraturan perundang-undangan.

Dari aspek pengendalian dan evaluasi, Bupati/walikota melalui kepala SKPD melakukan pengendalian dan evaluasi pengelolaan pasar tradisional. Pengendalian dan evaluasi dilakukan terhadap: kebijakan pengelolaan pasar tradisional; pengelola dan pedagang; pendapatan dan belanja pengelolaan pasar; dan sarana dan prasarana pasar.

Lalu bagaimana peran stakeholders dalam kebijakan pengembangan pasar tradisional? Istilah peran kerap diucapkan banyak orang. Sering kita mendengar kata peran dikaitkan dengan posisi atau kedudukan seseorang. Lebih jelasnya kata peran atau role dalam kamus oxford dictionary diartikan: Actor's part; one's task or function. Yang berarti aktor; tugas seseorang atau fungsi. Istilah peran dalam Kamus Besar Bahasa Indonesia mempunyai arti pemain sandiwara (film), tukang lawak pada permainan makyong, perangkat tingkah yang diharapkan dimiliki oleh orang yang berkedudukan di masyarakat. Ketika istilah peran digunakan dalam lingkungan pekerjaan, maka seseorang yang diberi (atau mendapatkan) sesuatu posisi, juga diharapkan menjalankan perannya sesuai dengan apa yang diharapkan oleh pekerjaan tersebut. Karena itulah ada yang disebut dengan role expectation. Harapan mengenai peran seseorang dalam posisinya, dapat dibedakan atas harapan dari si pemberi tugas dan harapan dari orang yang menerima manfaat dari pekerjaan/posisi tersebut. Dengan demikian dapat ditarik benang merah bahwa dalam sebuah peran di situ melekat hak dan kewajiban, ada goal/harapan yang ingin dicapai baik oleh pelaku maupun yang memberikan peran danada stardart/aturan yang harus diikuti aktor-stakeholder (pemangku peran atau kepentingan).
Istiningtyas (2008) mengidentifikasi beberapa stakeholders (pemangku kepentingan) dalam kebijakan pengembangan pasar tradisional, yaitu: (1) Bappeda, (2) Disperindagkop, (3) masyarakat pedagang, (4) UPTD, (5) pengelola swasta, (6) Dispenda, (7) DLHK, dan (8) DTKP. Idealnya, semua stakeholders yang berkepentingan dalam kebijakan pengembangan pasar tradisional dilibatkan dalam perencanaan dan pelaksanaan kebijakan tersebut. Masing-masing stakeholders yang terlibat memiliki kepentingan dan pengaruh yang berbeda-beda terhadap kebijakan pengembangan pasar tradisional. Hal ini dapat ditunjukkan dengan peranan atau keterlibatan masing-masing stakeholders dalam program pengembangan pasar tradisional. Keterlibatan stakeholders itu dapat mempengaruhi keberhasilan perencanaan dan pelaksanaan kebijakan pengembangan pasar tradisional dalam mencapai tujuannya.

Salah satu hasil dari studi Istiningtyas adalah, kriteria utama yang menyebabkan proses pembuatan kebijakan pengembangan pasar tradisional kurang tepat adalah tidak di libatkannya beberapa stakeholder dalam proses penyusunan kebijakan pengembangan pasar tradisional.

Kebijakan pengembangan pasar tradisional mulai dari tahap perencanaan, proses penyusunan program, pelaksanaan kebijakan hingga hasil yang diperoleh dari kebijakan yang telah dilaksanakan. Oleh karena itu, penting membandingkan kesesuaian antara proses perencanaan kebijakan dengan pelaksanaan kebijakan serta tujuan yang ingin dicapai dari kebijakan dengan hasil yang dicapai dan manfaat kebijakan bagi stakeholders yang terlibat (Syahribulan, 2012). Perencanaan dan pelaksanaan kebijakan pengembangan pasar tradisional tentunya dipengaruhi oleh tingkat kepentingan dan tingkat pengaruh stakeholders. Masing-masing stakeholders memiliki tingkat kepentingan dan pengaruh yang berbeda-beda. Intensitas pengaruh dan kepentingan stakeholders didasarkan pada bentuk interaksi, keuntungan, dan dampak yang dihasilkan terhadap kebijakan pengembangan pasar tradisional serta posisi yang kuat dalam setiap pengambilan keputusan yang akan dilakukan.

Jadi, terdapat beberapa stakeholders yang terkait dalam perencanaan dan pelaksanaan kebijakan pengembangan pasar. Penggolongan stakeholders dibuat berdasarkan tingkat kepentingannya terhadap kebijakan pengembangan pasar tradisional. Stakeholders primer merupakan mereka yang dipengaruhi secara langsung, baik secara positif (penerima manfaat) atau negatif (terkena dampak negatif) akibat pengembangan pasar tradisional, yaitu: kelompok pedagang, Badan Perencanaan Daerah (Bappeda), Dinas Perindustrian Perdagangan dan Koperasi (Disperindagkop), dan pihak pengelola pasar pemerintah (UPTD). Adapun stakeholders sekunder merupakan mereka yang terkait dengan kebijakan secara tidak langsung dalam proses pengembangan 
Tabel 1. Identifikasi dan Analisis Peran Stakeholders.

\begin{tabular}{|c|c|c|c|c|c|c|c|c|}
\hline \multirow{3}{*}{$\begin{array}{l}\text { Stakeholders } \\
\text { (yang } \\
\text { Mempengaruhi } \\
\text { atau yang } \\
\text { Dipengaruhi }\end{array}$} & \multicolumn{7}{|c|}{ Kriteria Evaluasi } & Keputusan \\
\hline & \multirow[t]{2}{*}{ Kepentingan } & \multirow[t]{2}{*}{ Sikap } & \multicolumn{2}{|r|}{ Kekuatan } & \multirow[t]{2}{*}{ Pengaruh } & \multirow[t]{2}{*}{ Total } & \multirow[t]{2}{*}{ Keterlibatan } & Tingkat \\
\hline & & & SDM & Finansial Pol. & & & & \\
\hline
\end{tabular}

Sumber: Abdrabo dan Hassan, 2007.

Keterangan:

- Sikap: 3 = sangat mendukung/menyetujui; 2 = cukup mendukung/ menyetujui; $1=$ netral; -2 = cukup menentang/menolak; $\&-3$ = sangat menentang.

- Kekuatan (SDM, finansial, dan politik): $5=$ sangat kuat; $4=$ kuat; $3=$ rata-rata; $2=$ lemah; \& $1=$ sangat lemah.

- Pengaruh: SDM + Finansial + Politik.

- Total: Sikap X Pengaruh.

- Keterlibatan: jika total < 10 (diabaikan); jika total > 10 (harus dilibatkan).

Keputusan: $10-20$ (penerima informasi); $20-30$ (pemberi pertimbangan); \& $>30$ (pengambil keputusan kebijakan).

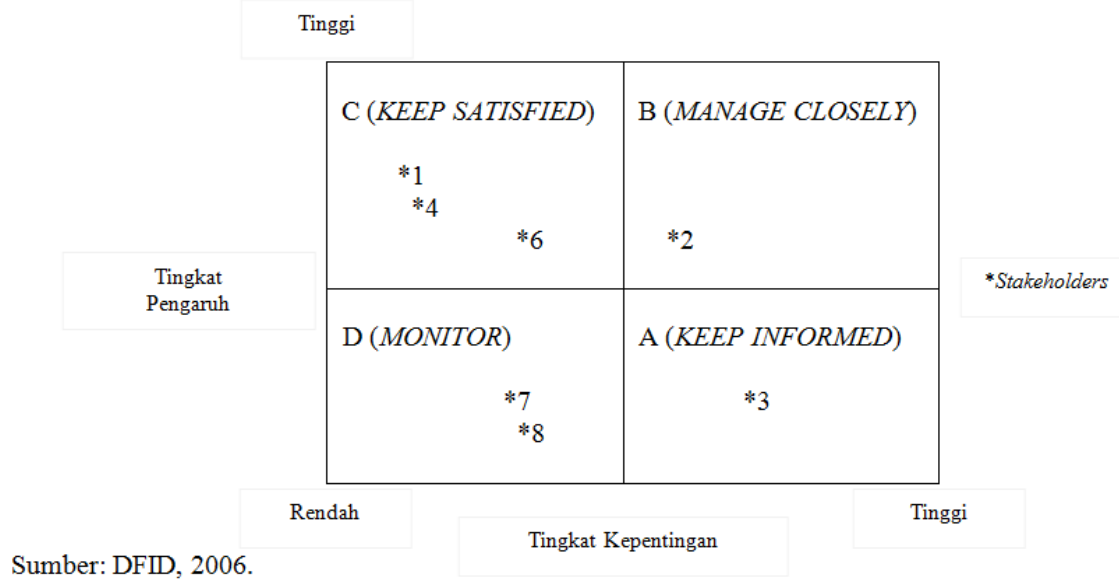

Gambar 1. Matriks Kepentingan dan Pengaruh Stakeholders

pasar tradisional. Pinak yang tergolong stakenolders sekunder adalah Dinas Lingkungan Hidup dan Kebersihan (DLHK), Dinas Pendapatan Daerah (Dispenda), Dinas Tata Kota dan Pemukiman (DTKP), dan pengelola pasar swasta.

Selanjutnya, untuk menilai kebijakan pengembangan pasar tradisional, diperlukan suatu analisis stakeholders yang terkait dengan kebijakan tersebut. Analisis stakeholders adalah sebuah proses sistematis untuk mengumpulkan dan menganalisis informasi secara kualitatif untuk menentukan kepentingan siapa yang harus diperhitungkan ketika mengembangkan atau melaksanakan suatu kebijakan atau program (Schmeer, 2007).

Umunya, kepentingan stakeholders dalam sebuah kebijakan dipengaruhi oleh faktor sosial, ekonomi, dan budaya. Pengaruh stakeholders yang berbeda-beda dalam suatu kebijakan dipengaruhi oleh politik, birokrasi, dan struktural.

Selanjutnya, alat analisis yang digunakan dalam kajian ini mengacu pada langkah-langkah di bawah ini:

1. Membuat tabel stakeholders seperti pada Tabel 1 .
2. Identı11kası partısıpası/peran stakenolders yang tepat.

a. Membuat ringkasan matriks partisipasi/peran untuk mengklarifikasi peranan yang harus dilaksanakan oleh semua stakeholders pada berbagai tahapan siklus program.

b. Membahas bersama stakeholders mengenai peran yang harus mereka lakukan, sehingga diketahui posisinya bila ditempatkan dalam matriks.

\section{Kotak A (Membuat Tetap Puas):}

Pihak yang sangat penting bagi kebijakan, tapi pengaruhnya rendah. Mereka membutuhkan inisiatif khusus jika ingin melindungi kepentingan mereka. Pihak ini harus terus diberikan informasi yang cukup mengenai kebijakan serta meyakinkan mereka bahwa tidak ada masalah besar yang timbul. Pihak ini seringkali sangat berguna bagi proses penyusunan kebijakan secara terperinci. 


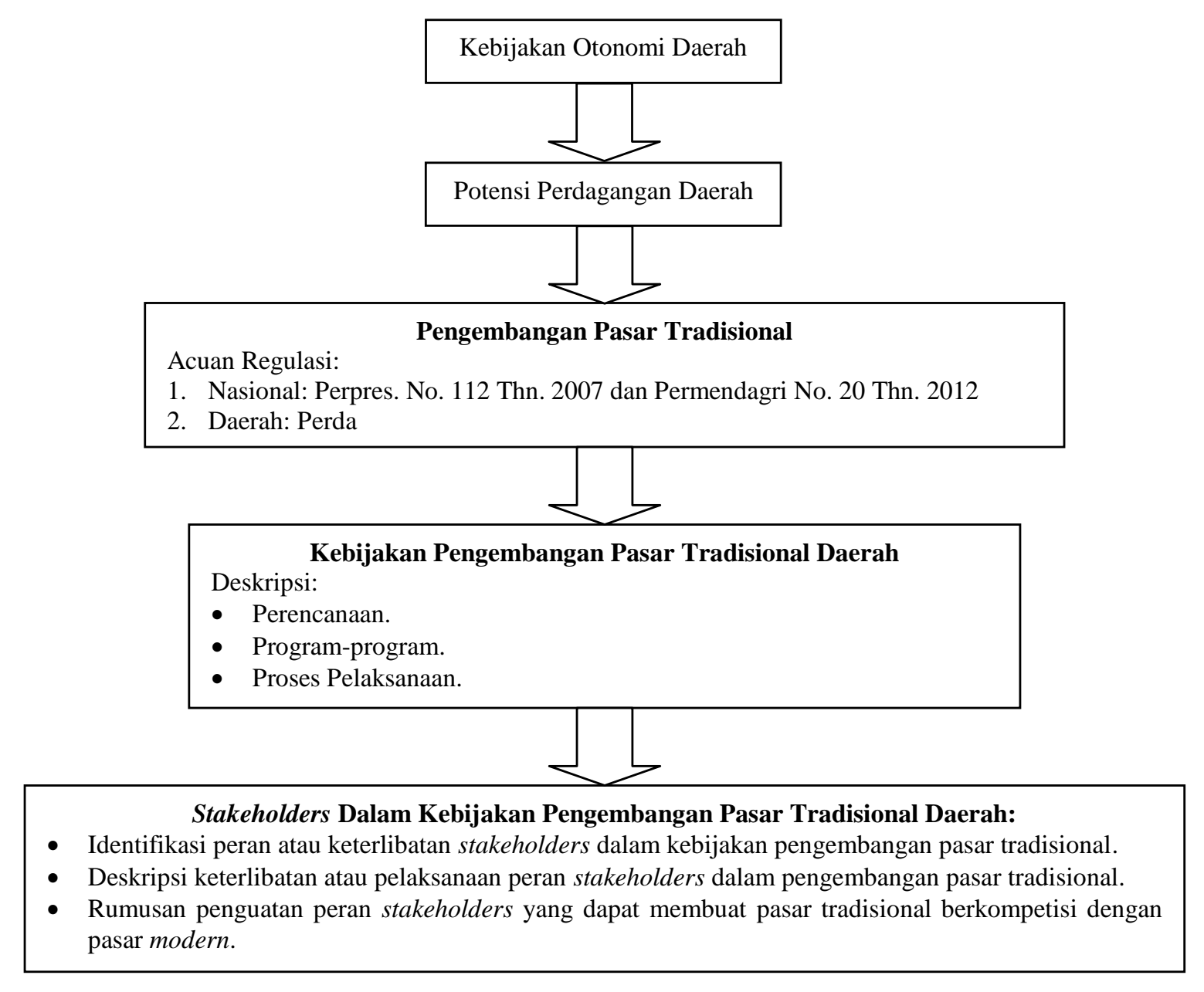

Gambar 2. Kerangka Pemikiran Kajian

Kotak B (Mengelola Hubungan Kerja yang Erat):

Pihak yang sangat penting bagi kebijakan, tapi juga sangat penting bagi pencapaian keberhasilan. Penyusun kebijakan dan donor perlu membina hubungan kerja yang baik dengan para pihak ini untuk memastikan adanya dukungan terhadap program. Stakeholders yang termasuk pihak ini harus dilibatkan secara penuh dalam setiap proses maupun penerapan kebijakan.

\section{Kotak C (Mengamati):}

Pihak yang berpengaruh besar, karena dapat mempengaruhi hasil kebijakan, tapi tidak memiliki minat/pengaruh terhadap kebijakan. Usaha nyata diperlukan untuk membuat mereka tetap puas dengan hasil kebijakan.

\section{Kotak D (Mendapatkan Informasi/Penerima Informasi): \\ Pihak yang berada pada prioritas rendah, tapi} membutuhkan monitoring dan evaluasi yang terbatas. Mereka tidak mungkin menjadi subyek kebijakan. Adapun kerangka pemikiran/alur pikir kajian ini dapat digambarkan secara skematis seperti pada Gambar 2.

\section{METODE PENELITIAN}

Kajian ini menggunakan pendekatan penelitian desktiptif kualitatif. Menurut Whitney (2000), penelitian deskriptif adalah pencarian fakta dengan interpretasi yang tepat. Eksplanasi secara deskriptif dalam kajian ini adalah membuat deskripsi atau gambaran secara sistematis, faktual, dan akurat mengenai fakta-fakta empiris yang berkaitan dengan peran atau keterlibatan stakeholders dalam kebijakan pengembangan pasar tradisional. Fakta-fakta peran stakeholders adalah fakta tentang kepentingan dan pengaruh (sikap dan kekuatan SDM, finansial, dan politik) stakeholders. Fakta-fakta yang ditemukan di lapangan akan ditafsirkan dengan tepat, dan selanjutnya menjadi dasar dalam menganalisis kajian ini.

\section{Lokasi}

Oleh karena keterbatasan waktu, tenaga, anggaran, dan agar kajian ini lebih mendalam, maka kajian ini hanya dilaksanakan di Provinsi Banten (Kota Serang). Pemilihan lokasi tersebut dilakukan secara sengaja (purposive), dengan pertimbangan 
yang lain bahwa daerah tersebut merupakan kota. yang cukup mengalami pertumbuhan ekonominya, terutama di sektor perdagangan. Hal ini tentunya membutuhkan kebijakan pengembangan sektor perdagangan, khususnya dalam hal pengembangan pasar tradisional untuk mengimbangi pertumbuhan sektor perdagangan yang pesat.

\section{Waktu}

Kajian ini dilaksanakan selama 3 (tiga) bulan, yaitu dari bulan Oktober sampai dengan bulan Desember 2013.

\section{Teknik Pengumpulan Data}

Pengumpulan data dalam kajian ini mengunakan teknik: (1) dokumentasi, dan (2) wawancara. Ada 2 (dua) jenis data yang dikumpulkan, yaitu data primer dan data sekunder. Data primer diperoleh dari hasil wawancara langsung dengan stakeholders dalam kebijakan pengembangan pasar tradisional, yaitu: (1) Asosiasi Pedagang Pasar (APP) atau Asosiasi Masyarakat Pedagang (AMP), (2) Dinas Koperasi, UKM, Perindag., atau Disperindagkop., (3) Badan Perencanaan Daerah (Bapeda), (4) Perusahaan Daerah (PD) Pasar atau Kantor Pengelolaan Pasar (KPP) atau UPTD Pasar, (5) Dinas Tata Ruang dan Cipta Karya (DTRCK) atau Dinas Tata Kota (DTK) atau Dinas PU/DPU, (6) Badan Pengelola Lingkungan Hidup (BPLH) atau Badan Lingkungan Hidup Daerah (BLHD), (7) Perusahaan Daerah (PD) Kebersihan, dan (8) Dinas Pengelola Keuangan dan Aset Daerah (DPKAD) atau Dinas Pendapatan, Pengelolaan Keuangan, dan Aset Daerah (DPPKAD) atau Dinas Pengelolaan Keuangan Daerah (DPKD). Data primer adalah data tentang tingkat kepentingan dan pengaruh (peran) stakeholders dalam kebijakan pengembangan pasar tradisional. Adapun data sekunder diperoleh dari dokumen dan studi pustaka sebagai data penunjang yang relevan dengan kajian ini.

\section{Instrumen}

Sesuai dengan kedua teknik pengumpulan data yang digunakan di atas, maka instrumen (alat) kajian atau alat pengumpulan data yang dipakai dalam dalam ini adalah: (1) ceklis dokumen, dan (2) pedoman wawancara terbuka.

\section{Informan}

Informan dalam kajian ini adalah stakeholders dalam kebijakan pengembangan pasar tradisional, yaitu: (1) Asosiasi Pedagang Pasar (APP) atau Asosiasi Masyarakat Pedagang (AMP), (2) Aparat Dinas Koperasi, UKM, Perindag., atau Disperindagkop., (3) Aparat Badan Perencanaan Daerah (Bapeda), (4) Pegawai Perusahaan Daerah (PD) Pasar atau Kantor Pengelolaan Pasar (KPP) atau UPTD Pasar, (5) Aparat Dinas Tata Ruang dan Cipta Karya (DTRCK) atau Dinas Tata Kota (DTK) atau Dinas PU/DPU, (6) Aparat Badan Pengelola Lingkungan Hidup (BPLH) atau Badan Lingkungan
Hidup Daerah (BLHD), (7) Pegawai Perusahaan Daerah (PD) Kebersihan, dan (8) Aparat Dinas Pengelola Keuangan dan Aset Daerah (DPKAD) atau Dinas Pendapatan, Pengelolaan Keuangan, dan Aset Daerah (DPPKAD) atau Dinas Pengelolaan Keuangan Daerah (DPKD).

\section{Teknik Analisis Data}

Analisis data dalam kajian ini menggunakan teknik deskriptif. Setelah data terkumpul, maka lalu diklasifikasikan menjadi 2 (dua) kelompok data, yaitu data kualitatif dan data kuantitatif. Terhadap data yang bersifat kualitatif (yang dihimpun melalui wawancara), yaitu yang digambarkan dengan katakata atau kalimat, dipisah-pisahkan menurut kategori untuk memperoleh kesimpulan. Adapun data yang bersifat kuantitatif (yang dihimpun melalui dokumentasi), yang berwujud angka-angka, diproses dengan cara dihitung, dijumlahlah, atau dipersentasekan, dan kemudian dideskripsikan.

\section{HASIL DAN PEMBAHASAN}

\section{Hasil}

Kota Serang adalah sebuah kota di Provinsi Banten, Indonesia. Serang merupakan ibukota Provinsi Banten. Serang berada tepat di sebelah Utara Provinsi Banten, serta dikelilingi oleh Kabupaten Serang di sebelah selatan, barat, dan timur, dan Laut Jawa di sebelah Utara. Serang dilintasi jalan tol lintas Jakarta - Merak. Kota Serang terdiri atas 6 kecamatan, yang dibagi lagi atas sejumlah kelurahan. Dahulu Serang merupakan bagian dari wilayah Kabupaten Serang, kemudian ditetapkan sebagai kota otonom pada tanggal 2 November 2007. Kota Serang terdiri atas: Serang, Cipocok Jaya, Curug, Kasemen, Taktakan, dan Walantaka. Kota Serang dan daerah sekitarnya terhitung istimewa secara budaya karena di sini dipertuturkan Bahasa Jawa Serang atau bahasa Jawa Banten.

Perkumpulan pedagang di Kota Serang dinamakan AMP (Asosiasi Masyarakat Pedagang) Kota Serang, yang anggotanya/pedagang merupakan sasaran dari program pasar tradisional.Disperindagkop Kota Serang merupakan unsur pelaksana otonomi daerah. Dinas ini berkedudukan di bawah dan bertanggung jawab kepada Walikota melalui Sekretaris Daerah. Dinas ini mempunyai tugas melaksanakan urusan pemerintahan daerah berdasarkan asas otonomi dan tugas pembantuan di bidang perindustrian, perdagangan dan koperasi. Salah satu bidang dalam dinas ini adalah Bidang Perdagangan, yang membawahkan: (1) Seksi Perdagangan Dalam dan Luar Negeri; (2) Seksi Pengelolaan Informasi dan Perlindungan Konsumen; dan (c) Seksi Pengelolaan dan Pengembangan Pasar.

Bapeda Kota Serang mempunyai tugas pokok melaksanakan penyusunan dan pelaksanaan kebijakan daerah di bidang perencanaan pembangunan daerah. Untuk melaksanakan tugas sebagaimana dimaksud, 


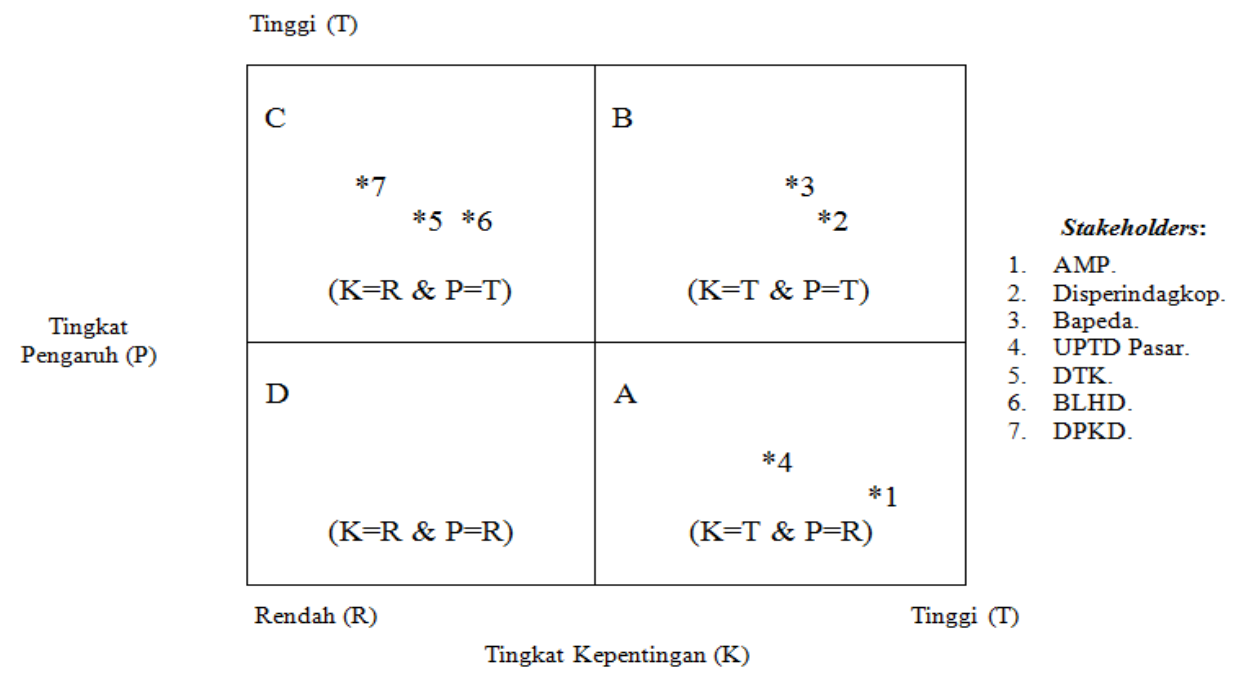

Sumber: Data Sekunder (Diolah).

Gambar 3. Matriks Kepentingan dan Pengaruh Stakeholders dalam Kebijakan Pengembangan Pasar Tradisional di Kota Serang Provinsi Banten

Badan Perencanaan Pembangunan Daerah mempunyai fungsi: (1) Penyusunan perencanaan pembangunan daerah; (2) Perumusan kebijakan teknis perencanaan pembangunan daerah; (3) Pengkoordinasian, penyusunan perencanaan pembangunan daerah; (4) Pembinaan, pengendalian dan fasilitasi pelaksanaan kegiatan bidang perencanaan pembangunan ekonomi dan penanaman modal, perencanaan sosial budaya, fisik dan prasarana serta program, penganggaran, penelitian, pengembangan dan statistik; (5) Pelaksanaan kegiatan penatausahaan Badan Perencanaan Pembangunan Daerah; dan (6) Pelaksanaan tugas lain yang diberikan oleh Walikota sesuai dengan tugas dan fungsinya.

UPTD Pasar Kota Serang memiliki tingkat kepentingan yang tinggi terhadap kebijakan pengembangan pasar tradisional, yaitu melaksanakan teknis pengelolaan pasar dan juga membina pedagang. Hal ini didasarkan pada tugas UPTD Pasar sebagai pengelola pasar yang berkaitan langsung dengan pedagang, yaitu melakukan pengelolaan pasar terutama dalam hal pendataan pedagang dan penarikan retribusi.

Dinas Tata Kota Serang (DTK) mempunyai tugas melaksanakan urusan pemerintahan daerah di bidang Penataan Ruang, Perumahan dan Permukiman dan Kebersihan berdasarkan asas otonomi dan tugas pembantuan. Dalam melaksanakan tugas Dinas Tata Kota Kota Serang menyelenggarakan fungsi: (1) penyusunan perencanaan di bidang Tata Ruang, Perumahan dan Permukiman serta Kebersihan, (2) perumusan kebijakan teknis di bidang Tata Ruang, Perumahan dan Permukiman serta Kebersihan, (3) pelaksanaan urusan pemerintahan dan pelayanan umum di bidang Tata Ruang, Perumahan dan Permukiman serta Kebersihan, (4) pembinaan, koordinasi, pengendalian dan fasilitasi pelaksanaan kegiatan di bidang Tata Ruang, Perumahan dan
Permukiman serta Kebersihan, (5) pelaksanaan kegiatan penatausahaan Dinas, (6) pembinaan terhadap Unit Pelaksana Teknis Dinas, dan (7) pelaksanaan tugas lain yang diberikan oleh Walikota sesuai dengan tugas dan fungsinya. Isu-isu strategis dinas ini adalah: (1) Diperlukannya peningkatan ketersediaan dan kualitas Perencanaan, Pemanfaatan serta Pengendalian Pemanfaatan Ruang, (2) Diperlukannya Peningkatan Pelayanan Persampahan, (3) Diperlukannya Peningkatan kualitas perumahan dan permukiman layak huni dan menurunnya kawasan permukiman kumuh, dan (4) Perlunya Peningkatan Ketersediaan dan kualitas Infrastruktur Permukiman.

DLHD Kota Serang merupakan unit kerja di Lingkungan Kota Serang yang mempunyai tugas membantu Walikota Serang dalam melaksanakan kewenangan desentralisasi, dekonsentrasi dan tugas pembantuan di bidang lingkungan hidup. Dalam penyelenggaraan tugas tersebut, maka fungsi Badan Lingkungan Hidup Daerah Kota Serang adalah melaksanakan hal-hal sebagai berikut: (1) Penyusunan rencana kerja lingkungan hidup; (2) Perumusan kebijakan teknis lingkungan hidup; (3) Pengkoordinasian, penyusunan rencana kerja lingkungan hidup; (4) Pembinaan, pengendalian dan fasilitasi pelaksanaan kegiatan bidang lingkungan hidup; (5) Pelaksanaan kegiatan penatausahaan Badan Lingkungan Hidup Daerah; dan (6) Pelaksanaan tugas lain yang diberikan oleh Walikota sesuai dengan tugas dan fungsinya.

DPKD Kota Serang adalah Perangkat Daerah/Institusi yang membantu Walikota dalam rangka melaksanakan manajemen keuangan daerah. Adapun yang menjadi dasar dibentuknya Dinas Pengelolaan Keuangan Daerah (DPKD) Kota Serang adalah Peraturan Daerah Serang Nomor 9 Tahun 2008 tentang Pembentukan dan Susunan Organisasi Dinas Daerah Kota Serang. Dinas Pengelolaan Keuangan 
Daerah mempunyai tugas melaksanakan urusan pemerintahan daerah bidang pengelolaan keuangan dan pendapatan berdasarkan asas otonomi dan tugas pembantuan. Dalam melaksanakan tugasnya, Dinas Pengelolaan Keuangan Daerah menyelenggarakan fungsi: (1) Penyusunan perencanaan bidang pengelolaan keuangan dan pendapatan; (2) Perumusan kebijakan teknis bidang pengelolaan keuangan dan pendapatan; (3) Pelaksanaan urusan pemerintahan dan pelayanan umum bidang pengelolaan keuangan dan pendapatan; (4) Pembinaan, koordinasi, pengendalian dan fasilitasi pelaksanaan kegiatan bidang keuangan dan pendapatan; (5) Pelaksanaan kegiatan penatausahaan Dinas; (6) Pembinaan terhadap Unit Pelaksana Teknis Dinas; dan (7) Pelaksanaan tugas lain yang diberikan oleh Walikota sesuai dengan tugas dan fungsinya.

\section{Pembahasan}

Hasil identifikasi lapangan menunjukkan terdapat beberapa stakeholders yang terkait dalam perencanaan dan pelaksanaan kebijakan pengembangan pasar tradisional di Kota Serang Provinsi Banten. Penggolongan stakeholders berdasarkan tingkat kepentingannya terhadap kebijakan pengembangan pasar tradisional.

Penggolongan yang dimaksud adalah: (1) Stakeholders primer, yaitu yang dipengaruhi secara langsung, baik secara positif (penerima manfaat) atau negatif (terkena dampak negatif) akibat pengembangan pasar tradisional. Pihak yang tergolong stakeholders primer adalah: (a) Asosiasi Masyarakat Pedagang (AMP), (b) Disperindagkop., (c) Badan Perencanaan Daerah (Bapeda), dan (d) UPTD Pasar; dan (2) Stakeholders sekunder, yaitu yang terkait dengan kebijakan secara tidak langsung dalam proses pengembangan pasar tradisional. Pihak yang tergolong stakeholders sekunder ini adalah: (a) Dinas Tata Kota (DTK), (b) Badan Lingkungan Hidup Daerah (BLHD), dan (c) Dinas Pengelolaan Keuangan Daerah (DPKD).

Perencanaan dan pelaksanaan kebijakan pengembangan pasar tradisional dipengaruhi oleh tingkat kepentingan dan tingkat pengaruh stakeholders, dan masing-masing stakeholders memiliki tingkat kepentingan dan pengaruh yang berbeda-beda. Selain itu, intensitas pengaruh dan kepentingan stakeholders didasarkan pada bentuk interaksi, keuntungan, dan dampak yang dihasilkan terhadap kebijakan pengembangan pasar tradisional, termasuk posisi yang kuat dalam setiap pengambilan keputusan yang akan dilakukan. Hasil analisis peran stakeholders dalam kebijakan pengembangan pasar tradisional di Kota Serang Provinsi Banten dirangkum dalam lampiran Tabel 2.

Lampiran Tabel 2 menunjukkan 3 (tiga) bentuk peran atau tingkat keterlibatan stakeholders dalam kebijakan pengembangan pasar tradisional di Kota Serang selama ini, yaitu: (1) AMP Kota Serang terlibat/ berperan sebagai penerima informasi, (2)
Disperindagkop serta Bapeda Kota Serang terlibat/berperan sebagai pengambil keputusan, dan (3) UPTD Pasar, DTK, BLHD, dan DPKD Kota Serang terlibat/berperan sebagai pemberi pertimbangan.

Selanjutnya, Tabel 2 tersebut digunakan sebagai dasar dalam penyusunan matriks kepentingan dan pengaruh stakeholders dalam kebijakan pengembangan pasar tradisional di Kota Serang Provinsi Banten, seperti yang ditunjukkan pada Gambar 3 .

Tidak semua stakeholders tersebut di atas yang berkepentingan dalam kebijakan pengembangan pasar tradisional dilibatkan dalam pengambilan keputusan kebijakan pengembangan pasar tradisional di Kota Serang. Hanya pihak Disperindagkop dan Bapeda Kota Serang yang terlibat dalam pengambilan keputusan kebijakan tersebut. Sementara pihak UPTD Pasar dan AMP Kota Serang, walaupun dilibatkan, tetapi mereka diposisikan sebagai pemberi pertimbangan dan penerima informasi saja yang berkaitan dengan proses perencanaan dan penerapan kebijakan tersebut, bukan ikut dilibatkan dalam pengambilan keputusan. Adapun untuk pihak DTK, DPKD, dan BLHD Kota Serang, yang posisinya sebagai pemberi pertimbangan, tidak selamanya dilibatkan dalam setiap pembahasan kebijakan pengembangan pasar tradisional. Padahal, pihak-pihak tersebut memiliki pengaruh yang tinggi dalam kebijakan daerah yang berkaitan dengan masingmasing Tupoksinya.

Kondisi Ideal Peran Stakeholders. Kondisi ideal yang seharusnya terjadi dari tingkat kepentingan dan pengaruh stakeholders yang terlibat dalam kebijakan pengembangan pasar tradisional dapat dilihat pada Gambar 4.

Kotak A (Keep Informed). Pihak yang sangat penting bagi kebijakan pengembangan pasar tradisional, tapi pengaruhnya rendah. Mereka membutuhkan inisiatif khusus jika ingin melindungi kepentingan mereka. Pihak ini harus terus diberikan informasi yang cukup mengenai kebijakan serta meyakinkan mereka bahwa tidak ada masalah besar yang timbul. Pihak ini seringkali sangat berguna bagi proses penyusunan kebijakan pengembangan pasar tradisional secara terperinci.

Kotak B (Manage Closely). Pihak yang sangat penting bagi kebijakan pengembangan pasar tradisional, dan juga sangat penting bagi pencapaian keberhasilannya. Penyusun kebijakan pengembangan pasar tradisional dan donor perlu membina hubungan kerja yang baik dengan para pihak ini untuk memastikan adanya dukungan terhadap program pasar tradisional. Stakeholders yang termasuk pihak ini harus dilibatkan secara penuh dalam setiap proses maupun penerapan kebijakan pengembangan pasar tradisional.

Kotak C (Keep Sattisfied). Pihak yang berpengaruh besar, karena dapat mempengaruhi hasil kebijakan pengembangan pasar tradisional, tetapi 
tidak/kurang memiliki minat (pengaruh) terhadap kebijakan tersebut. Usaha nyata diperlukan untuk merasa dirugikan. Pada sisi yang lain, dengan di libatkannya UPTD Pasar dan AMP dalam

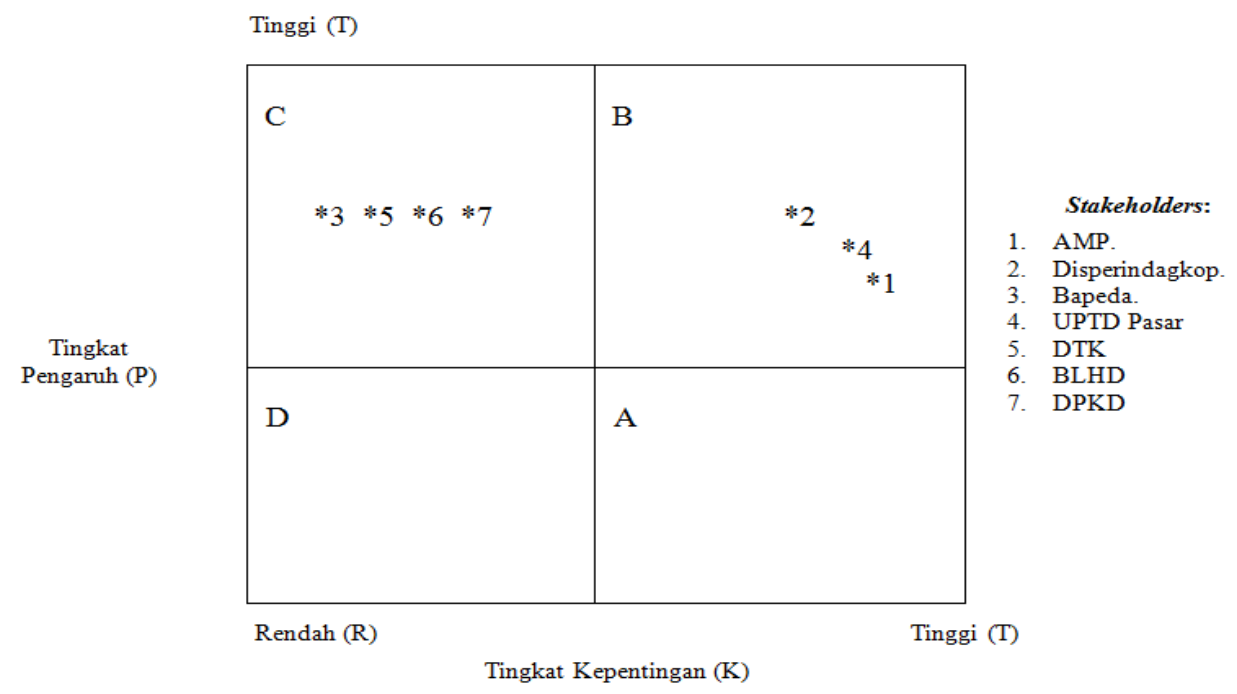

Sumber: Data Sekunder (Diolah).

Gambar 4. Matriks Kepentingan dan Pengaruh Stakeholders pada Kondisi Ideal dalam Implementasi Kebijakan Pengembangan Pasar Tradisional Kota Serang.

membuat mereka tetap puas dengan hasil kebijakan pasar tradisional.

Kotak D (Monitor). Pihak yang berada pada prioritas rendah, tetapi membutuhkan monitoring dan evaluasi yang terbatas. Mereka tidak mungkin menjadi subyek kebijakan pasar tradisional, seperti pengelola pasar swasta.

Pada kondisi ideal, seharusnya tingkat kepentingan dan pengaruh stakeholders memiliki hubungan yang erat. Stakeholders yang memiliki kepentingan yang tinggi, akan memiliki kekuatan yang tinggi pula dalam kebijakan pengembangan pasar tradisional. Namun faktanya, stakeholders yang memiliki kepentingan tinggi belum tentu memiliki kekuatan pengaruh yang tinggi dalam mempengaruhi kebijakan pengembangan pasar tradisional, yaitu pihak AMP. Pihak-pihak ini memiliki kepentingan yang tinggi terhadap kebijakan pengembangan pasar tradisional namun tidak memiliki tingkat pengaruh yang tinggi dalam pengambilan keputusan. Konsekuensinya, dalam perencanaan dan penyusunan kebijakan, Pemda/Pemkot. kurang mendapat informasi mengenai kondisi riil di lapangan karena tidak di libatkannya kedua pihak tersebut. Akibatnya, kebijakan yang dihasilkan pun menjadi kurang tepat karena lebih mementingkan kepentingan dari Pemda/Pemkot saja tanpa mengakomodir kepentingan masyarakat dan pedagang di pasar tradisional.

UPTD Pasar dan AMP yang memiliki kepentingan tinggi seharusnya memiliki tingkat pengaruh yang tinggi pula dalam kebijakan pengembangan pasar tradisional, sebab kebijakan pengembangan pasar tradisional disusun untuk mengakomodir kepentingan pedagang sehingga dengan adanya kebijakan ini pedagang tidak akan perencanaan kebijakan, maka dukungan terhadap kebijakan akan bertambah, dalam artian tidak ada pedagang yang akan menolak kebijakan. Dengan demikian, kemungkinan kebijakan yang digulirkan untuk berhasil dilaksanakan akan semakin besar.

Keterlibatan pedagang dalam kebijakan pengembangan pasar tradisional ini, yaitu dengan keterlibatan komunitas pedagang pasar melalui asosiasi pedagang untuk menjadi mitra pemerintah dalam mengelola pasar. Dengan di libatkannya pedagang dalam mengelola pasar, maka mereka juga akan ikut menjaga kebersihan dan kenyamanan pasar sehingga kondisi lingkungan pasar akan lebih bersih dan rapi. Selain itu, dengan di libatkannya pedagang, akan lebih menarik konsumen, sebab pedaganglah yang mengerti kondisi riil konsumennya.

Bagi UPTD Pasar dan AMP, pada kondisi ideal, bukan hanya dilibatkan dalam hal penyaluran data dan informasi mengenai potensi pasar tradisional dan upaya pengembangannya, melainkan juga sangat perlu dilibatkan dalam pengambilan keputusan karena kedua pihak tersebut memiliki kepentingan yang tinggi. Adapun bagi stakeholders yang memiliki kepentingan yang rendah dengan pengaruh yang tinggi (Bapeda, DTK, DPKD, dan BLHD) perlu terus dilibatkan untuk memberi pertimbangan dalam setiap pembahasan kebijakan pengembangan pasar tradisional yang berkaitan dengan masing-masing Tupoksinya.

\section{SIMPULAN}

Peran atau keterlibatan stakeholders dalam kebijakan pengembangan pasar tradisional di Kota Serang adalah: (a) AMP Kota Serang terlibat/berperan 
sebagai penerima informasi, (b) Disperindagkop serta Bappeda Kota Serang terlibat/berperan sebagai pengambil keputusan, dan (c) UPTD Pasar, DTK, BLHD, dan DPKD Kota Serang terlibat/berperan sebagai pemberi pertimbangan.

Dalam kenyataannya, tidak semua stakeholders (penerima informasi dan pemberi pertimbangan) dilibatkan dalam kebijakan pengembangan pasar tradisional di Kota Serang. Padahal stakeholder ini sangat diperlukan untuk memberikan masukan atau pertimbangan dalam kebijakan pengembangan pasar tradisional sesuai dengan masing-masing Tupoksinya.

Penguatan peran stakeholders yang perlu dilakukan agar pasar tradisional dapat berkompetisi dengan toko moderen dan pusat perbelanjaan adalah: (a) Seluruh stakeholders yang berperan/terlibat dalam kebijakan pengembangan pasar tradisional harus dilibatkan dalam perencanaan dan pelaksanaan kebijakan pasar tradisional. Selain stakeholders pengambil keputusan, semua stakeholders penerima informasi dan stakeholders pemberi pertimbangan juga harus dilibatkan untuk memberikan masukan dan pertimbangan; (b) Untuk UPTD Pasar dan AMP, sebaiknya bukan hanya dilibatkan dalam hal penyaluran data dan informasi mengenai potensi pasar tradisional dan upaya pengembangannya, melainkan juga sangat perlu dilibatkan dalam pengambilan keputusan (diposisikan sebagai stakeholders pengambil keputusan), karena kedua pihak tersebut memiliki kepentingan yang tinggi. Dengan di libatkannya UPTD Pasar dan AMP dalam perencanaan dan pengambilan keputusan, maka dukungan terhadap kebijakan akan bertambah, dalam artian tidak ada pedagang yang akan menolak kebijakan. Dengan demikian, kemungkinan kebijakan yang digulirkan untuk berhasil dilaksanakan akan semakin besar; dan (c) Penguatan kewenangan, kebijakan/regulasi, SDM, dan anggaran.

\section{DAFTAR PUSTAKA}

Abdrabo, Mohamed A. dan Mahmoud A. Hassan. Stakeholder Analysis. http:www.wadi-unifi.com. Diakses tanggal 30 Agustus 2007.

Biset. 2008. "A Stakeholder Theory of the Modern Corporation", dalam L.B. Pincus (ed.), Perspectives in Business Ethics. Singapore: McGraw Hill, 1998, hlm. 171-181.

Branco, Manuel Castelo dan Lúcia Lima Rodriguez. 2007. "Positioning Stakeholder Theory within the Debate on Corporate Social Responsibility (CSR)", EJBO (Electronic Journal of Business Ethics and Organization Studies), Vol. 12, No. 1(2007), hlm. 5-15.

Chariri, A.,\& Ghazali, I. 2007. Teori Akuntansi. Semarang: Badan Penerbit UNDIP.

DFID. Manajemen Daur Proyek dan Penggunaan Kerangka Kerja Logis. http://www.deliveri. org. Diakses tanggal 30 Agustus 2006.

Donaldson, T. dan L. E. Preston. 1995. "The Stakeholder Theory of the Corporation: Concepts, Evidence, and Implications", Academy of Management Review, Vol. 20 No. 1, 1995, hlm. 65-91.

Firman. 2013. Perancangan Analisis Kebijakan Pengembangan Pasar Tradisional Di Kabupaten Cirebon. Jakarta: JBPTITBPP.

Freeman, R. E. 1984. Strategic Management: A Stakeholder Approach. Boston: Pitman Publishing.

Hill, Michael. 2006. Social Policy: A Comparative Analysis. London: Prentice Hall.

Istiningtyas, Dyah Arum. 2008. Analisis Kebijakan dan Strategi Pengembangan Pasar Tradisional. Bogor: FP-IPB.

Mursitama, Tirta Nugraha. 2011. Pengembangan Pasar Tradisional. Jakarta: BINUS University Institute for Business and Diplomatic Studies (BIBDS).

Pemangku Kepentingan: http:www.id.wikipedia.org/ wiki/ pemangku_kepentingan. Diakses tanggal 15 Januari 2012.

Pengaruh Pemangku Kepentingan Terhadap Kebijakan: http://www.smeru. or.id/. Diakses tanggal 6 Maret 2012.

Pengelompokan Stakeholders: http://www.suarapublik.org/Artikel/stakeholder.ht m. Diakses tanggal 18 Mei 2012.

Rietbergen, Jennifer. 2008. Participation and Social Assessment, Tools and Techniques. Deepa Narayan: IBRD-WB.

Republik Indonesia. 2007. Peraturan Presiden RI No. 112 Tahun 2007 Tentang Pernataan dan Pembinaan Pasar Tradisional, Pusat Perbelanjaan, dan Toko Modern.

----------.-. 2012. Peraturan Menteri Dalam Negeri No. 20 Tahun 2012 Tentang Pengelolaan dan Pemberdayaan Pasar Tradisional.

Riyadi, E.S. 2008. "Landasan Teoretis bagi Tanggung Jawab Sosial Perusahaan: dari Pemegang Saham (Shareholder) ke Pemangku Kepentingan (Stakeholder)", Dignitas, Volume V No. II Tahun 2008.

Rudito, dkk. 2004. Corporate Social Responsibility: Jawaban Bagi Modal Pembangunan Indonesia Masa Kini. Jakarta: ICSD.

Schmeer, Kammi. Stakeholder Analysis at a Glance. $\mathrm{http} / / w w w$.lachsr.org. Diakses tanggal 7 Januari 2008.

Syahribulan. 2012. Studi Kelembagaan Dalam Implementasi Kebijakan Pengelolaan Pasar Tradisional Di Kota Makassar. Makassar: FISIP UNHAS.

Whitney, F.L. 2000. A Four Year Continuaution Study of A Teachers College Class. New York: The Macmillan Co.

Wibisono, Yusuf. 2007. Membedah Konsep dan Aplikasi CSR. Gresik: Fascho Publishing, Utama. 


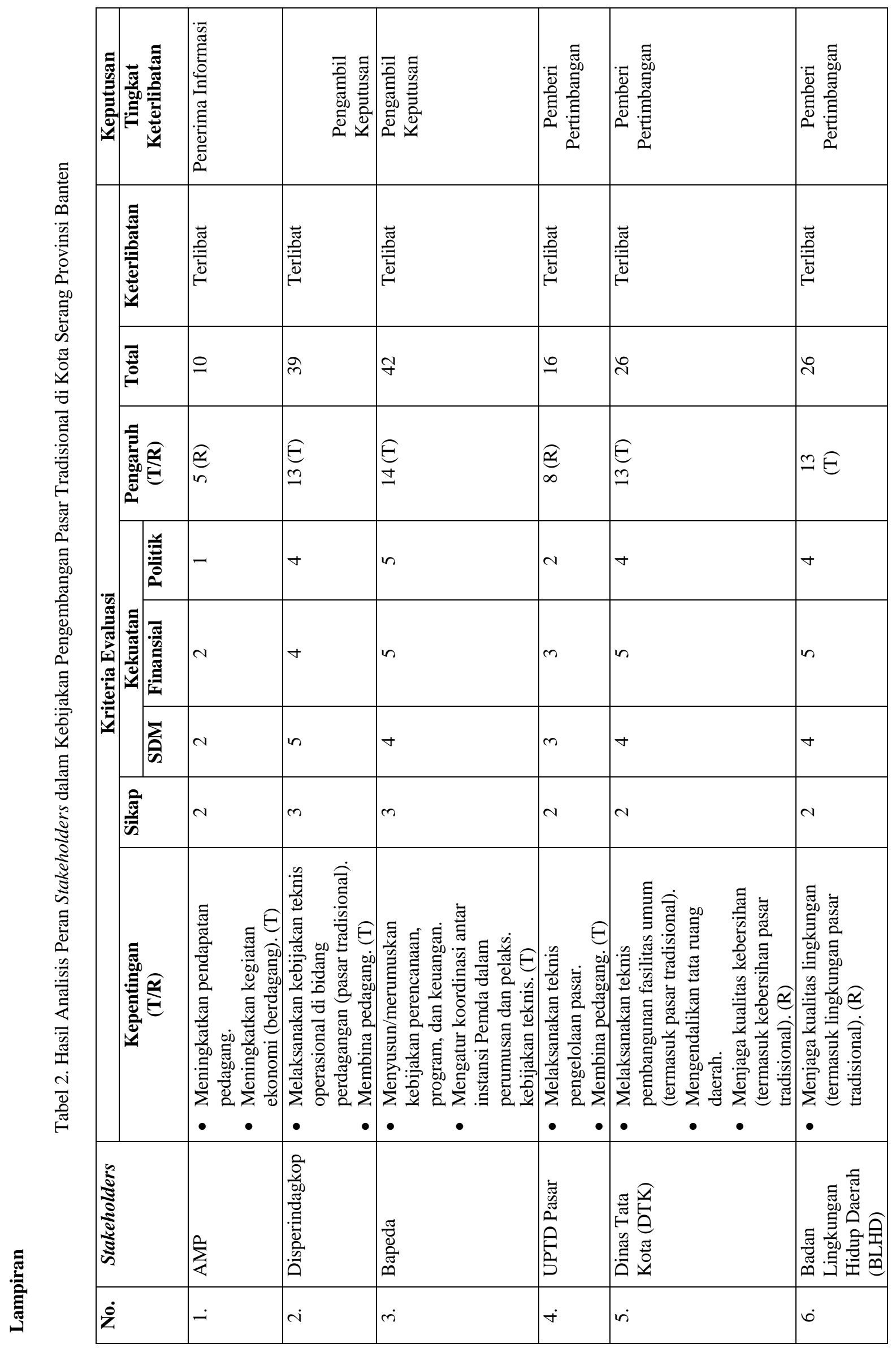

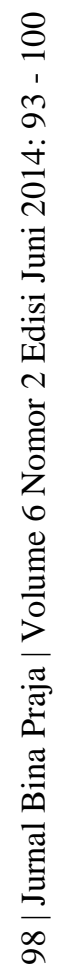




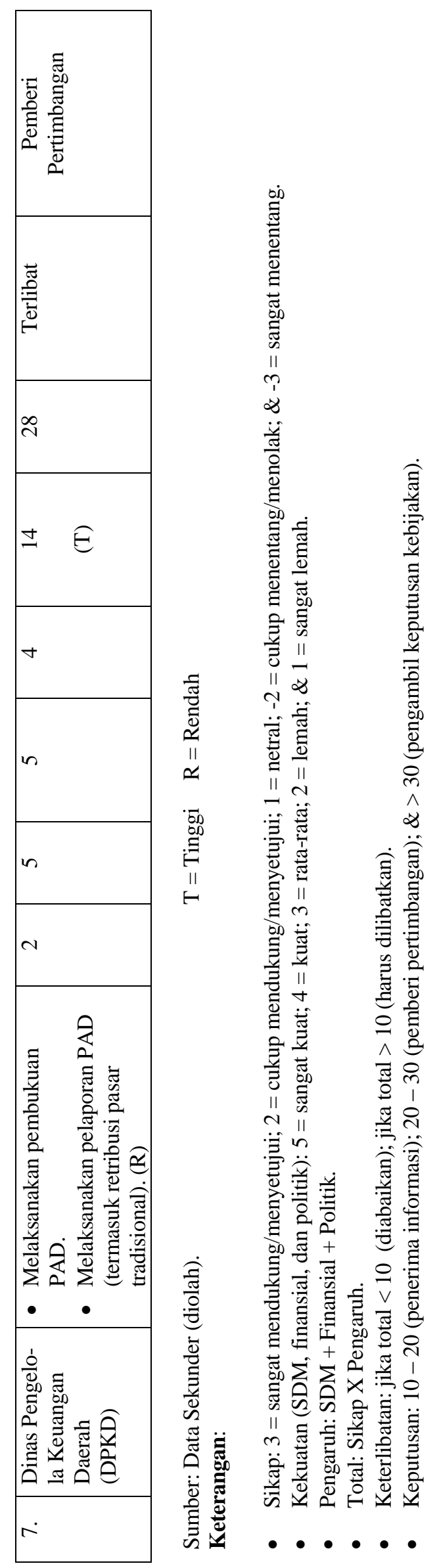

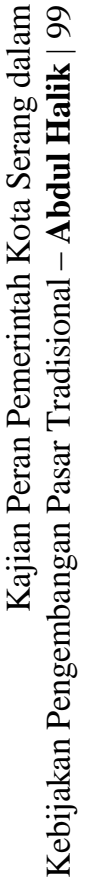


